\title{
Social Media Use among Students of Federal Polytechnic Ilaro, Ogun State, Nigeria: Implication on Academic Performance
}

\author{
${ }^{1}$ IRO-IDORO, Charlotte Bose \& ${ }^{2}$ JIMOH, Tajudeen Adisa \\ Office Technology and Management Department, The Federal Polytechnic, Ilaro, P. M. B. 50, Ilaro, \\ Ogun State, Nigeria.
}

\begin{abstract}
This study investigated the impact of social media use on the academic performance of students of the Federal Polytechnic, Ilaro, Ogun State. Survey approach with the use of questionnaire was employed in gathering data for the study. Two hypotheses were formulated and data were collected using a questionnaire tagged Social Media Use and Students' Academic Performance Scale (SMUSAPS) The population comprises all students of the Federal Polytechnic, Ilaro but the sampling was confined to only the HND students. 70 HND students were randomly selected from each of the five schools of the Institutions - Applied Science, Communication and Information Technology, Engineering, Environmental Studies and Management Studies to make a total of 350 students selected as sample for the study. Data collected were analyzed using frequency counts and percentage; and the hypotheses were tested using Chi-square Likelihood Ratio Test at 0.05 level of significance. The results revealed that participation in social media impairs dedication of students to academic activities and that it has negative effect on students' academic performance. The study recommended that since there are perceived opportunities and advantages in the use of social media networks, Lecturers, parents, guardians and sponsors should always make efforts to educate students on the adverse consequence of excessive use of social media to ensure that students' addiction to social media especially for social activities alone is reduced and facilitate learning outcomes among the students.
\end{abstract}

Keywords: Academic Performance, ICT, Learning, Polytechnic Students and Social Media

\section{INTRODUCTION}

Modern invention in communication technology has broadened the scope of communication through Information and Communication Technologies. This advancement in communication technology has also affected internet use and has engendered a tremendous access and participation in social networking and interaction on internet sites known as social media. The online world has changed dramatically as a result of the inventions of social media, through which young men and women exchange ideas, feelings, personal information, pictures, videos e.t.c. at astonishing rate. The trend in social media technology has become an important means of online discourse where people create content, share it, bookmark it, etc. As a result of its ease of use, speed and reach, social media is fast gaining attention in modern discourse and setting agenda in topics that range from culture, environment, education, politics, technology, and entertainment [1]. Communicating through the internet and social networking websites is quite different from communicating in person-to- person situation. When users communicate through these websites, they use things like instant message (IM) and chatting [2]. They are modern interactive communication channels through which people connect to one another, share ideas, experiences, pictures, messages and information of common interest. What distinguishes the social media from the conventional means of communication is their interactive nature which allows the audience to participate in it from any part of the world they reside [3].

Social networking websites provide tools by which people can communicate, share information, and create new relationships. With the popularity of social networking websites on the rise, our social interaction is affected in multiple ways [2]. As we adapt to our increasingly technological world, the way web users interact and talk to each other has changed and continues to change. This interactive nature of the social media confers an unprecedented popularity on them, as they have the capabilities of educating, informing, entertaining and inflaming the audience. Above all, they possess a "contagious and outreaching influence" which the conventional media lack. This potential is most likely what [3] refers to as "unstoppable power of the social media". The foregoing points to the fact that social media have become an integral part of the young people and students' social life and this serve as platforms for users to interact and relate with their peers. The emergence of social media as a result of advancement in technology and expansion in internet software has raised concerns among academics especially on its impacts on academic life of students and learning outcomes [4]. Students at all levels of learning now have divided attention to studies, as a result of available opportunities to be harnessed 
from social media. The use of social networking among students has become more and more popular. Students use it as a way to make connection not only on campus, but with friends outside school. It helps many people feel as though they belong to a community. Due to this increased popularity and use, researchers are questioning the phenomena impact of the social media on the academic life of students and the extent to which the time spent by students on the social media sites affect learning outcomes in schools [9] in [2].Internet sites focus heavily on building online metropolitan areas certain to align with common interests or activities. Within the portion of collaborative learning, the internet sites handled the large problems and have assisted to solve a few individuals' problems, with the aid of interactive affiliate and encourage investigative-based and collaborative activities among students in higher education [5]. This open access for active participation and can therefore create opportunities for effective learning. Linked with this principle of collaborative development among learners, social media enable learners and teachers to share and publish information as a result of the learning activity (e.g. course materials such as course syllabus, course notes, assignments, test cases, etc) and invite feedback from peers. By publishing and presenting their work to a wide audience through blogs, wikis, or podcasts, learners benefit from the opportunity to appropriate new ideas, and transform their own understanding through reflection [6]. At higher level of education, more complex academic tasks are handled and the new generations of students are perceived to understand that social media and social technologies are influential to learning.

However, several researches have been carried out on the challenges that are connected with using internet and social media in higher education. [7] noted that internet addiction is significantly and negatively related to students' academic performance, as well as emotional attributes. [8] corroborates [7] assertion that the negative influence of internet is only on excessive users and not on all users. [9] reported that social media sites have negative effect on students' academic performance. [10] as cited in [2] found that facebook users often time experience poor academic performance. In the same way, [11] found that frequent use of mobile phones is correlated with academic difficulty and failure among university students. [12] as cited in [1] avers that the social networking sites and blogs which are being used today with tremendous passion and zeal have transformed the way of using internet in recent years by describing online tools and utilities which allow users for communication, participation and collaboration of information online. Today's young generation, especially teens and youth are using technology through innovative ways due to which they are referred to as millennials and have changed the ways we think, work and communicate even though they are in formative years of their life. Today's youth because of these social networking sites have become technology addicts and are quite introverted.[13] examined the impact of facebook on undergraduate academic performance and submitted that social media have negative impact on students. According to the study, the more students use facebook, the more it affects their academic performance. [14] stated that a research study on the mechanisms of media effects on academic outcomes reported that the widespread use of media among college students may compromise academic performance. The study also shows that the use of social media on cell phones may lower the grades of female students. [15] in a study on the use of social media among students of Ohio Dominican University observed that the grade point averages of students who use social network are significantly lower than that of students who do not use social networks. [16] noted that most of the younger students use social networking sites mainly for socialising activities, rather than for academic purpose. [16] further observed that most of the students do feel that social networking sites have more positive impact on their academic performance. In another study conducted by [17], it was revealed that students use social network mainly for making friends and chatting. The result showed that only 26 percent of the students (respondents) indicated that they use social media for academic purpose. Different research results show that the internet and social media are important factors that can influence educational performance of students positively or adversely in modern school environment. Parents and school administrators and other stakeholders also show concern over the alarming rate at which students make use of the internet and participate in social media interaction resulting in less dedication and time to study. Despite these worries, many students continue to utilize these sites on a daily basis. It is against this background that this research examines the impact of social media on the academic life and performance among Polytechnic students in Ogun State, Nigeria.

\section{STATEMENT OF THE PROBLEM}

Social networking sites and applications - Yahoo Messenger, Facebook, Blackberry Messenger (BBM), Google talk, Google plus, skype, snapchat, WhatsApp, e.t.c. are used by most people to interact with old and new friends, physical or internet friends. There have been a lot of debates on various platforms and media as to the impact that social media have on society and its effect on academic performance of students. Previous studies reported drop in students' grades and academic performance, and lack of time for studies as consequences of social media network participation and a high addiction rate among students, use of more time on social networking sites than in academic activities, wrong usage of grammar and spelling in social media discourse as well as distracting students from their studies. As a result of perceived available opportunities to be 
harnessed from social media and the growing use of the social networking sites, students at all levels of higher education now have divided attention to studies. Technology is a double-edged sword, as such people's perceptions are diverse on the widespread adoption of social media among students. Hence, this study investigates the extent of usage of social media among Polytechnic Students and the impact of the social media on the academic performance.

\section{OBJECTIVES OF THE STUDY}

The purpose of this study was to determine the influence of social media participation on academic life and learning outcomes among Polytechnic Students in Ogun State, Nigerian. The study seeks to ascertain whether social media use among Polytechnic Students reduce their commitment to academic activities and time devoted to study. It was also the aim of this study to examine the relationship between social media use and academic performance of the students.

\section{HYPOTHESES}

1. Participation in social media networks will not impair students' dedication to academic activities.

2. Social media use has no significant negative impact on academic performance of students.

\section{METHODOLOGY}

This study used the survey design to examine the characteristics studied. The study was carried out at the Federal Polytechnic, Ilaro, Ogun State. The study population involved all students of the Institution but the sampling was limited to only Higher National Diploma students. Hence, the sampling was purposive and simple random sampling was then used to select a total of 350 Higher National Diploma students from the five schools of the Polytechnic, that is, Pure and Applied Sciences, Communication and Information Technology, Engineering, Environmental Studies and Management Studies. 70 HND students were selected from each of the School to make the sample size. Questionnaire was the main instrument used for collecting data. The questionnaire was divided into two sections - Section A was designed to specifically collect information on the social media networks mostly used by the students, the purpose for which the social media platforms were used while Section B contains questions on the effect of the social media use on the students academic performance. The instrument was pretested on students of Moshood Abiola Polytechnic to determine its reliability and validity. Out of the 350 questionnaire distributed, 338 was completed and retrieved from the students. This represents 97 percent of the total questionnaire administered.

\section{RESULTS}

The data generated were analysed using percentage, frequency counts, mean and standard deviations through the use of Statistical Package for the Social Sciences (SPSS). It is important to note the following which were used in the data analysis of this work. In Section B of the questionnaire, respondents were provided with options on a 4-point Likert Scale, that is, SA = Strongly Agree, A = Agree, SD = D = Disagree and Strongly Disagree, which were then analysed for testing the hypotheses.

Table 1: Analysis of Responses on favourite Social Media networks mostly used by students of Federal Polytechnic, Ilaro, Ogun State.

\begin{tabular}{|l|c|c|}
\hline Social Media platforms & Frequency & Percentage \\
\hline Facebook & 149 & 44 \\
\hline Skype & 1 & 0 \\
\hline Instagram & 27 & 8 \\
\hline Whatsapp & 132 & 39 \\
\hline Twitter & 5 & 1 \\
\hline BBM & 21 & 6 \\
\hline Linkedln & 2 & 1 \\
\hline Total & 337 & 100 \\
\hline
\end{tabular}

The above table indicates the social media platform which the students considered as their individual favourite social networks and are mostly used. The percentage count indicates that Facebook is the most widely used social media platform among the students with $44 \%$ and followed by Whatsapp with $39 \%$. The above table is depicted in the chart below: 


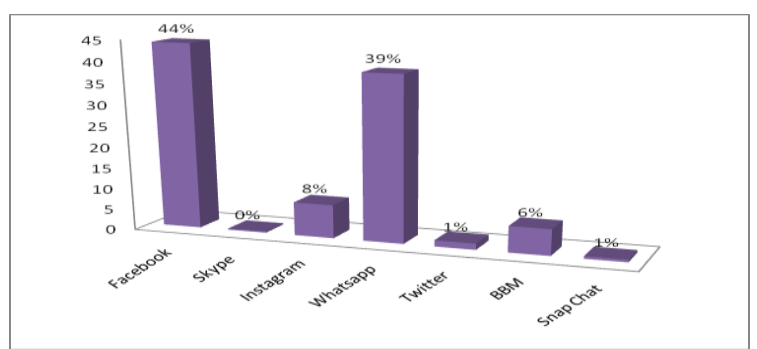

Table 2: The purpose for which students use social media networks

\begin{tabular}{|l|c|c|}
\hline Social Media platforms & Frequency & Percentage \\
\hline Chatting & 146 & 43 \\
\hline Downloading Music/Video & 22 & 7 \\
\hline Uploading Music/Video & 25 & 7 \\
\hline Posting Photos & 124 & 37 \\
\hline $\begin{array}{l}\text { Exchanging ideas with } \\
\text { classmates }\end{array}$ & 21 & 6 \\
\hline Total & 338 & 100 \\
\hline
\end{tabular}

Field Survey, 2017

Table 2 shows the purposes for which students visit social media sites. The responses indicated that the social media platforms were mostly used by students for chatting and posting of photos. $43 \%$ and $37 \%$ of the total responses were indicated for chatting and posting of pictures respectively. Other purposes as indicated in the table are downloading and uploading of music and videos, while the students indicated that they exchange ideas with their classmates on an average response of $21 \%$. The above frequency table is depicted by the chart below.

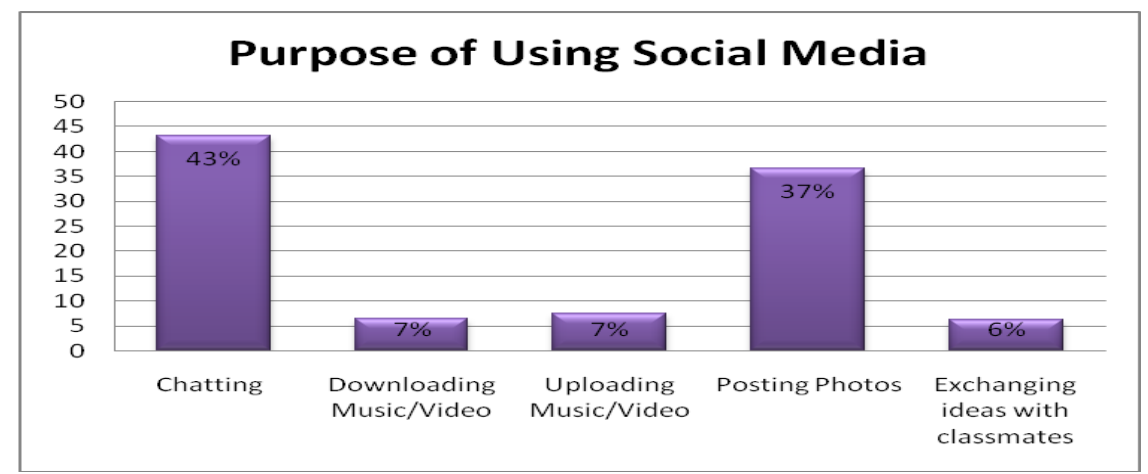

Table 3: Class of Cumulative Grade Point Average (CGPA) of Sample

\begin{tabular}{|c|c|c|c|c|c|}
\hline & & $\begin{array}{c}\text { Frequenc } \\
\mathrm{y}\end{array}$ & Percent & $\begin{array}{c}\text { Valid } \\
\text { Percent }\end{array}$ & $\begin{array}{c}\text { Cumulative } \\
\text { Percent }\end{array}$ \\
\hline \multirow{5}{*}{$\begin{array}{l}\text { Vali } \\
\text { d }\end{array}$} & $2.00-2.49$ & 18 & 5.3 & 5.3 & 5.3 \\
\hline & $\begin{array}{l}2.50- \\
2.99\end{array}$ & 193 & 57.1 & 57.1 & 62.4 \\
\hline & $3.0-3.49$ & 105 & 31.1 & 31.1 & 93.5 \\
\hline & $\begin{array}{l}3.50- \\
4.00 \\
\end{array}$ & 22 & 6.5 & 6.5 & 100.0 \\
\hline & Total & 338 & 100.0 & 100.0 & \\
\hline
\end{tabular}

Source: Field survey, 2017

Table 4.1.3 analyzed the class of cumulative grade point average (CGPA) of the respondents. It showed that $18(5.3 \%)$ of the respondents were between $2.00-2.49,193(57.1 \%)$ of the respondent were between $2.50-2.99$, $105(31.1 \%)$ of the respondents are between $3.0-3.49$ and $22(6.5 \%)$ of the respondents were between $3.50-$ 4.00 . 
Table 4: Frequency Counts and Mean Values

\begin{tabular}{|c|c|c|c|c|c|}
\hline $\begin{array}{l}\text { Social Media and Students' } \\
\text { Dedication to Academic Activities }\end{array}$ & SA & A & $\mathrm{D}$ & SD & mean \\
\hline $\begin{array}{l}\text { Students devote much time to using } \\
\text { the social media than reading books. }\end{array}$ & 96 & 110 & 67 & 65 & 2.701183 \\
\hline $\begin{array}{l}\text { Students use social media to chat } \\
\text { even during classes. }\end{array}$ & 75 & 77 & 99 & 87 & 2.414201 \\
\hline $\begin{array}{l}\text { Students' assignments suffer as a } \\
\text { result of social media use }\end{array}$ & 97 & 94 & 75 & 72 & 2.639053 \\
\hline $\begin{array}{l}\text { Students always think of having } \\
\text { access to their favourite social } \\
\text { networks }\end{array}$ & 119 & 132 & 43 & 44 & 2.964497 \\
\hline $\begin{array}{l}\text { Students who use social media } \\
\text { during classes are likely not grasp } \\
\text { the content of the lecture }\end{array}$ & 156 & 114 & 43 & 25 & 3.186391 \\
\hline $\begin{array}{l}\text { Online social media distract students } \\
\text { from their study }\end{array}$ & 132 & 90 & 51 & 65 & 2.85503 \\
\hline $\begin{array}{l}\text { Social Media and Students' } \\
\text { Academic Performance }\end{array}$ & SA & A & $\mathrm{D}$ & SD & $X$ \\
\hline $\begin{array}{l}\text { Social media make students to lose } \\
\text { focus of their studies }\end{array}$ & 120 & 143 & 34 & 41 & 3.011834 \\
\hline $\begin{array}{l}\text { Students now rely on social media to } \\
\text { get information about class activities }\end{array}$ & 85 & 115 & 63 & 75 & 2.621302 \\
\hline $\begin{array}{l}\text { Reliance on information from class } \\
\text { group encourage absenteeism }\end{array}$ & 43 & 73 & 110 & 112 & 2.139053 \\
\hline $\begin{array}{l}\text { Exposure to social media have } \\
\text { negative effect on students' } \\
\text { academic performance }\end{array}$ & 99 & 110 & 66 & 63 & 2.724852 \\
\hline $\begin{array}{l}\text { Participation in social media may } \\
\text { result in poor academic performance }\end{array}$ & 98 & 111 & 69 & 60 & 2.730769 \\
\hline $\begin{array}{l}\text { Addiction to social media networks } \\
\text { usually results into drop in CGPA }\end{array}$ & 113 & 109 & 56 & 60 & 2.813609 \\
\hline
\end{tabular}

Field Survey, 2017

For the two hypotheses, the following were generated

\begin{tabular}{|l|r|c|c|c|}
\hline Table 5: Model Fitting Information \\
\hline Model & $\begin{array}{c}\text { Model Fitting } \\
\text { Criteria }\end{array}$ & \multicolumn{2}{|c|}{ Likelihood Ratio Tests } \\
\cline { 2 - 5 } & $\begin{array}{c}-2 \text { Log } \\
\text { Likelihood }\end{array}$ & Chi-Square & df & Sig. \\
\hline $\begin{array}{l}\text { Intercept } \\
\text { Only }\end{array}$ & 879.787 & & & \\
\hline Final & 3.406 & 876.381 & 39 & .000 \\
\hline Table 6: Pseudo R-Square & & & \\
\hline Cox and Snell & .925 & & & \\
\hline Nagelkerke & .994 & & & \\
\hline McFadden & .970 & & & \\
\end{tabular}




\begin{tabular}{|l|c|r|r|r|}
\hline Table 7: Likelihood Ratio Tests \\
\hline Effect & $\begin{array}{c}\text { Model Fitting } \\
\text { Criteria }\end{array}$ & \multicolumn{3}{|c|}{ Likelihood Ratio Tests } \\
\cline { 2 - 5 } & $\begin{array}{c}\text {-2 Log } \\
\text { Likelihood of } \\
\text { Reduced } \\
\text { Model }\end{array}$ & Chi-Square & df & Sig. \\
\hline Intercept & $3.406^{\mathrm{a}}$ & .000 & 0 & \\
\hline Q4 & $23.406^{\mathrm{b}}$ & 16.206 & 6 & .041 \\
\hline Q10 & $63.015^{\mathrm{b}}$ & 59.609 & 6 & .000 \\
\hline Q11 & $21.660^{\mathrm{b}}$ & 18.254 & 9 & .032 \\
\hline Q14 & $14.194^{\mathrm{b}}$ & 8.788 & 6 & .002 \\
\hline Q15 & $20.932^{\mathrm{b}}$ & 17.526 & 6 & .003 \\
\hline
\end{tabular}

The chi-square statistic is the difference in -2 log-likelihoods between the final model and a reduced model. The reduced model is formed by omitting an effect from the final model. The null hypothesis is that all parameters of that effect are 0 .

a. This reduced model is equivalent to the final model because omitting the effect does not increase the degrees of freedom

b. Unexpected singularities in the Hessian matrix are encountered. This indicates that either some predictor variables should be excluded or some categories should be merged.

\section{DISCUSSION}

Table 5 gives a log likelihood ratio of the model summary in which all the parameter co-efficient are non-zero based on the chi-square value of 876.381 with a significant value of 0.000 which less than the critical value of $0.05 \%$. Table 7 shows the likelihood ratio test and shows that the difference in the $2 \log$ likelihood between the final model and the reduce model is given as 0.000 and coefficient of the parameter for each factors are 16.206 (Students devote much time to using the social media than reading books), 59.609 (Online social media distract students from their study), 18.284 (Social media make students to lose focus of their studies), 8.788 (Exposure to social media have negative effect on students' academic life) and 17.526 (Participation in social media may result in poor academic performance). From the likelihood ratio test it revealed that the chisquare calculated value is 8.788 with significant value of 0.002 . Since the significant value is less than $0.05 \%$, we reject the null hypothesis as the P-value is 0.001 which is less than critical value of 0.05 Therefore, we accept the alternate hypothesis and conclude that participation in social media networks will impair students' dedication to academic activities.

Also, the likelihood ratio test revealed that the chi-square calculated value is 17.526 with significant value of 0.003 . Since the significant value is less than $0.05 \%$, we reject the null hypothesis since the P-value is 0.001 which is less than critical value of 0.05 . Therefore, we accept the alternate hypothesis and conclude that Social media use has negative impact on students' academic performance. From the results, we reject the null hypothesis that participation in social media networks will not impair students' dedication to academic activities and the alternate hypothesis is accepted. This implies that students' participation in social media platforms impair their dedication to academic activities. This result clearly indicates that majority of Students participate on social media platforms and devote much of their time to using the social media than reading books. This social media addiction is also reflected in the use of the platform during lectures as student always like to keep themselves updated on their favourite social media networks as indicated in Table 4. These on the whole result in poor dedication to academic activities. This results is in tandem with [8] that students at all levels of learning now have divided attention to studies, as a result of social media and [7] that internet addiction is significantly and negatively related to students' commitment to academic activities.

The results also indicate a rejection of the second null hypothesis that social media use has no significant negative impact on academic performance of students. It was found that Social media use by the students leads to loss of focus on studies as students now rely on social media to get information about class and school activities. Students' addiction to social media networks was also found to result into poor performance and drop in cumulative grade points of the addicted students. This shows that students use of social media as negative impact on academic performance. This corroborates [9] that social media sites have negative effect on students' academic performance. The result also supports [14] that the widespread use of media among college students may compromise academic activities and learning outcomes. 


\section{CONCLUSION}

This study examined the effect of social media use on the academic performance of students in Federal Polytechnic, Ilaro, Ogun State, Nigeria. The study shows that a large percentage of student of Federal Polytechnic, Ilaro use smart mobile phones with facility and applications for social media and they use social media platforms mostly for social activities. This habit reduces the amount of time dedicated to study. The result indicates that the students use the social to upload pictures, download music and chat with near and distant friends. Addictions to social media make some students to use the platform even during lectures. It is concluded that social media use among students of the Federal Polytechnic, Ilaro is high and this impairs their devotion to academic activities and contribute to drastic fall in reading culture among the students. The study also concludes that excessive participation of student on social media networks and consequent addiction to the social media could result in poor academic performance among of the addicted students.

\section{RECOMMENDATIONS}

Based on the foregoing, it is recommended that:

- Lecturers, parents, guardians and sponsors should always make efforts to educate students on the adverse consequence of excessive use of social media on their academic performance. This should be a continuous exercise to ensure that students' addiction to social media especially for social activities alone is reduced.

- Students should make efforts on their own to reduce the amount of time spent on social activities via the social media network and make use of the technology for the purpose of learning and research.

- Use of mobile phones and other smart devices during lectures should be frowned at in polytechnics and other institutions of learning while management of the schools should impose punitive sanctions on erring students.

\section{REFERENCES}

[1] Asur, S. \&. Huberman, B. A. (2010). Predicting the Future with Social Media. California: Palo Alto.

[2] Owusu-Acheaw, M. \& Larson, A. G. (2015). Use of Social Media and its Impact on Academic Performance of Tertiary Institution Students: A Study of Students of Koforidua Polytechnic, Ghana. Journal of Education and Practice, Vol.6 (6).

[3] Ezeah G. H., Asogwa, C. E. \& Obiorah, E. I. (2013). Social Media Use among Students of Universities in South-East Nigeria. IOSR Journal Of Humanities And Social Science (IOSR-JHSS) Vol. 16 (3).

[4] Asemah E. S., Okpanachi R. A., and Edegoh L. O.N. (2013). Influence of Social Media on the Academic Performance of the Undergraduate Students of Kogi State University, Anyigba, Nigeria. Research on Humanities and Social Sciences. Vol.3 (12) Retrieved on $10^{\text {th }}$ March, 2017 from www.iiste.org

[5] Waleed M. A. \& Mohd S. O. (n.d). The Impact of Social Media use on Academic Performance among university students: A Pilot Study. Journal of Information Systems Research And Innovation

[6] Dale, C. \& Pymm, J. (2009). Podagogy - The iPod as a Learning Technology. Active Learning in Higher Education, 10(1).

[7] Jeong, T. G. (2005). The Effect Of Internet Addiction and Self Control on Achievement of Elementary School Children. Korean Journal of Yeolin Education. Vol 5 (3).

[8] Seo, W. S (2004). Internet Usage and Life Satisfaction of Youths. Journal of Information Policy Vol.11 (2).

[9] Choney, S. (2010). Facebook Use Can Lower Grades by 20 Percent, Study Says. Retrieved on $10^{\text {th }}$ March 2017 from http://www.msnbc.com/id/39038581/ns.technology_and_science-tech_and_gadgets/.

[10] Khan, U. (2009). Facebook student underachieve in exams. Daily Telegraph, Retrieved on July, 2013, from http://www.telegraph.co.uk/educationnews.html

[11] Sanchez-Martinez and Otero (2009). Factors Associated with Cell Phone Use in Adolescents in the Community of Madrid (Spain). Cyberpsychology Behaviour, Vol. 12.

[12] Rather, A. A. (2013). Overuse of Facebook and Academic Grades: An Inverse Correlation. IOSR Journal of Humanities and Social Science (IOSR-JHSS.) Vol. 12 (6).

[13] Moon, A. L. (2011). Impact of Facebook on Undergraduates' Academic Performance: Implications for educational Leaders. Central Michigan University, Retrieved on 14 February, 2017 from http://www.iiste.org.

[14] Nauert, R. (2013). Social media, Facebook and Twitter Use May Harm Grades of College Freshman. Retrieved $10^{\text {th }}$ march, 2017 from http://psychcentral.com/news/2013/04/12/social-media-use-may-harmgrades-of-collegefreshman/53711.html. Accessed 16/08/2013

[15] Karpinski, A, C. \& Duberstein, A. (2009). A Description of Facebook Use and Academic Performance among Undergraduate and Graduate Students. San Diego, California: American National Research Association.

[16] Oye, N. (2012). Students' Perception of Social Networking Sites' Influence on Academic Performance. International Journal of Social Networking and Virtual Communication Vol. 1. (1). 
[17] Shana, L. B .(2012). The Influence of Social Networking Sites on Students' Academic Performance in Malaysia. Retrieved $14^{\text {th }}$ February, 2017 from http//utechacademic.edu.shanleebrown.

[18] Asemah, E. S and Edegoh, L. O. N. (2013). Influence of new media sexual contents on the sexual behaviour of Kogi State University Students. Journal of Research and Contemporary Issues. Vol. 7 (1\& 2). 